\title{
Tribunal clears obesity researcher of fraud
}

\section{Declan Butler, Paris}

A French tribunal has ruled that there are no grounds for the prosecution of Bernard Bihain on charges of 'forgery and use of forgeries'. Bihain, an obesity researcher, quit French public research in 1998 amid allegations of scientific misconduct.

Bihain's work on the identification and cloning of a molecule involved in fat degradation was queried in 1997 by members of his lab at the University of Rennes 1. An internal inquiry commissioned by the French research ministry concluded that the testimony of several whistle-blowers raised doubts about certain results produced by the lab (see Nature 391, 519-520; 1998).

But an independent international scientific inquiry promised by the science ministry was dropped in October 1998 after Bihain closed his lab (see Nature 393, 203; 1998 and Nature 395, 829; 1998). Bihain went on to become vice-president of physiological genomics at Genset, a French biotechnology company, and later chief scientific officer of the US-French company ValiGen.

The new ruling, by the Tribunal de Grande Instance in Rennes, concludes a separate judicial investigation of some aspects of the affair. It was launched in December 1998, when the public prosecutor brought charges on the basis of a preliminary inquiry by the fraud squad which raised the question of "an alteration of the truth in the translation of the results of experiments ... to make them coincide with a hypothesis

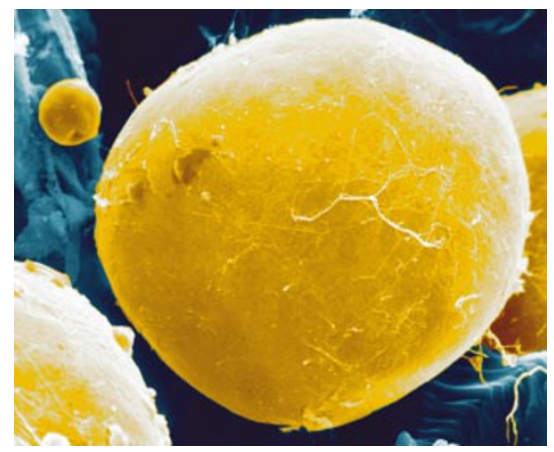

Questions over research on fat cells (pictured) sparked accusations of scientific misconduct.

developed by Mr Bihain" (see Nature 391, 825; 1998 and Nature 394, 308; 1998).

The judicial investigation heard testimony from several researchers, who had made allegations of misconduct. In addition other testimony questioned the experimental competence of several of the whistleblowers, and Bihain himself accused them of making false accusations.

In reaching its decision on the charges, the tribunal was only permitted by law to consider certain limited classes of documents. This is because the misdemeanour 'faux et usage de faux' ('forgery and use of forgeries') applies only to a "document or other medium of expression of which the object is, or effect may be, to provide evidence of a right or of a situation carrying legal consequences". This is not to say, how-

\section{Astronomers try to save Mars probe}

\section{David Cyranoski, Tokyo}

Japanese scientists will this month begin a last-ditch effort to save the Nozomi Mars probe, the country's first planetary mission.

The US\$848-million Nozomi was designed by Japan's Institute of Space and Astronautical Science (ISAS) to investigate the red planet's atmosphere and its interaction with the solar wind (see Nature 423, 473; 2003).

But Nozomi ran into trouble soon after its July 1998 launch. A swing by Earth in December 1998 — intended to accelerate the probe using the planet's gravitational pull - failed to give it enough speed to reach Mars. Attempts to correct its course by firing its engines drained its fuel tanks. And during another Earth swing-by in April 2002, a solar flare damaged its powersupply system.

The flare seems to have damaged a circuit breaker that regulates the flow of electricity to some of the craft's essential systems, including its heater. The breaker now "works too much, turning off and on continuously", says Yasunori Matogawa, ISAS scientist and director of Kagoshima Space Station from where Nozomi was launched.

Following a third, apparently successful, swing around Earth last week, the probe should finally reach Mars next January. But without the heater, the spacecraft cannot thaw the fuel it has left to manoeuvre itself into orbit around the red planet.

Later this month, ISAS scientists will try to fix the problem, sending successive commands to turn the power supply on. They hope that this will eventually burn out the circuit breaker, leaving the power switched on.

Matogawa says that they will probably know within the next couple of weeks whether the mission is likely to be saved. But even if initial efforts fail, they will keep trying until November. "I'd say there's a 50/50 chance," Matogawa says. ever, that the tribunal did not look at other documents to understand the wider context.

The court concluded that the allegations of "scientific fraud" generally were "essentially a controversy of a scientific nature" arguments among experts over methods, data interpretation and other elements of "ordinary experimental debate".

Michel Philippe, a researcher at the publicly funded laboratory of developmental biology and genetics at the University of Rennes 1, who took part in an earlier internal inquiry by the university, says he regrets that the promised independent, international scientific inquiry into the case was not conducted. INSERM, the French national biomedical agency, "has been unable to set up its own expert committee, and is now trusting a decision that was not made by scientists", he says.

But in a statement, INSERM said that it is delighted that the ruling has "put a definitive end to this affair and returned the honour to one of its researchers". Christian Bréchot, the agency's director general, says that the decision "honours the scientific integrity and the respect of the ethical rules common to all the researchers of the agency".

Bihain returned to INSERM last year as a researcher at the Nancy Centre of Clinical Investigation (see Nature 418, 467; 2002). Bréchot personally handled Bihain's re-appointment, and INSERM's unit of scientific integrity, which was set up in the aftermath of the Bihain affair, was not consulted. Bréchot points out that he asked an international team of experts to review Bihain's past research and future plans, and that the results were generally positive. Bihain's future research will be subject to the agency's usual regular evaluation procedures, Bréchot adds.

Bernard Bigot, director of the cabinet of science minister Claudie Haigneré, told Nature that the affair is now closed, and that the ministry has no intention of revisiting it. Bigot is familiar with the episode: in 1997 he was research director at the ministry and set up the initial internal inquiry that received testimony from whistle-blowers. Bigot subsequently carried out his own inquiry into the affair, and in December 1997 he submitted a report to the ministry, clearing Bihain's laboratory of misconduct. "The conclusion is the same as it was five years ago," says Bihain: "that there was no scientific fraud."

Bihain, who claims to have been the victim of vendettas at the University of Rennes 1 , hopes that the ruling will put an end to any suspicion that people may have held about him. The allegations and media coverage of the case "destroyed my credibility at the international level", he says. "I have continued to present my results to my peers while being an 'accused' researcher, whereas I never cheated in anything." 